Justyna Szymańska (D) https://orcid.org/0000-0001-7488-7941

Uniwersytet Ekonomiczny w Katowicach, Kolegium Ekonomii, Katedra Badań Strategicznych i Regionalnych, Katowice, justyna.szymanska@ue.katowice.pl

\title{
Przekształcenia siedzib gmin wiejskich w miasta - oczekiwania władz lokalnych w kontekście urbanizacji
}

Streszczenie: Współcześnie urbanizacja jest coraz częstszym zjawiskiem. W wielu krajach stale wzrasta liczba miast oraz ludności miejskiej. Tematem wartym uwagi staje się więc poszukiwanie przyczyn przekształceń siedzib gmin wiejskich w miasta. Główne cele artykułu to rozpoznanie oczekiwań władz lokalnych, związanych z przekształcaniem siedzib gmin wiejskich w miasta, oraz ustalenie, w jakim stopniu ta zmiana wpływa na oczekiwane przez władze lokalne korzyści z niej wynikające. Motywacje do przekształceń oraz oczekiwane korzyści z nich płynące zostały przeanalizowane na przykładzie siedmiu gmin w Polsce: Urzędowa, Mielna, Wiślicy, Radoszyc, Otynia, Łagowa i Józefowa nad Wisłą. W tym celu dokonano charakterystyki wybranych gmin, a następnie przy użyciu wywiadu ustrukturyzowanego wskazano przyczyny zmiany siedziby gminy oraz oczekiwania władz tych miejscowości. Z przeprowadzonych badań wynika, że w większości przypadków władze lokalne oczekują głównie wzrostu prestiżu miejscowości oraz większych możliwości pozyskiwania nowych źródeł finansowania.

Słowa kluczowe: urbanizacja, gminy wiejskie, przekształcenia siedzib gmin, miasta JEL: R58, R11, R50, R10 


\section{Wprowadzenie}

Procesy urbanizacji wsi i miast w globalnym świecie przybierają w ostatnich dekadach szczególnie na sile. Zgodnie z danymi Banku Światowego oraz ONZ w 2021 roku w miastach mieszka już 4,2 mld ludzi (The World Bank, 2020), a ich udział do 2050 roku szacowany jest na 68\% ogółu ludności świata (United Nations, 2018). Wynika z tego, że w 2050 roku w miastach będzie mieszkać 7 na 10 ludzi na świecie, co zwiększy liczbę mieszkańców miast do 6 mld (The World Bank, 2020). W większości krajów występuje i przez następne lata utrzymywać się będzie tendencja przyrostu liczby ośrodków miejskich, a tym samym liczby ludności miejskiej. Współcześnie globalizacja wywiera duży wpływ nie tylko na miasta, ale także na ośrodki wiejskie, które, aby nie uzależniać się od lepiej rozwiniętych miast, zmuszone są do intensywnego rozwoju (Bański, 2013: 24-25).

Zgodnie z wizją opisaną przez Jerzego Bańskiego (2013: 115) wieś w perspektywie 2050 roku najprawdopodobniej będzie bardziej różnorodna, aktywna i atrakcyjna niż obecnie. Interesujący w tym kontekście staje się coraz powszechniejszy, także w polskich warunkach, temat związany z przekształceniami siedzib gmin wiejskich w miasta, w tym szczególnie poszukiwanie przyczyn oraz poznawanie oczekiwań lokalnych interesariuszy związanych z tego rodzaju zmianą. Kwestia transformacji siedzib wsi w ośrodki miejskie może być interesująca także z perspektywy władz lokalnych, które de facto są inicjatorami tego rodzaju zmiany, dokonują jej formalnego przeprowadzenia, a także formułują określonego rodzaju oczekiwania. W tym kontekście ciekawe może okazać się rozpoznanie, $w$ jakim stopniu zmiana siedziby gminy z wsi w miasto wpływa na oczekiwane przez władze lokalne korzyści wynikające z takiej transformacji.

Mając na uwadze powyższe, celem artykułu jest rozpoznanie oczekiwań władz lokalnych, związanych z przekształceniem siedzib gmin wiejskich w miasta, oraz ustalenie, w jakim stopniu tego rodzaju zmiana wpływa na oczekiwania formułowane w kategoriach korzyści. Artykuł został podzielony na trzy części. W pierwszej dokonano przybliżenia zagadnień urbanizacji i rozwoju gmin wiejskich. W drugiej zaprezentowano przekształcenia zachodzące współcześnie w gminach wiejskich w polskich warunkach. W trzeciej zaś przedstawiono badania empiryczne związane z procesem przekształcania siedzib siedmiu wybranych gmin. W zakresie rozpoznania oczekiwań władz lokalnych odnośnie do badanego procesu przekształceń wykorzystano metodykę wywiadu ustrukturyzowanego. Kwestionariusz składał się z ośmiu pytań dotyczących przyczyny przekształcenia siedziby gminy z wsi w miasto, wpływu różnych czynników na rozwój gminy i transformację jej siedziby, dalszego rozwoju oraz oczekiwanych korzyści związanych ze zmianą siedziby gminy w miasto. Ostatnia część artykułu zawiera wnioski sformułowane w kontekście analizy oczekiwań władz miejskich i zestawienia ich z realnymi możliwościami analizowanych miast oraz sprawdzenia, $\mathrm{w}$ jakim stopniu analizowane miejscowości mogą te korzyści osiągnąć. 


\section{Urbanizacja i rozwój gmin wiejskich}

Na rozwój gmin wiejskich wpływa wiele różnych, często niepowiązanych ze sobą czynników. Powoduje to, że rozwój obszarów wiejskich jest trudnym zagadnieniem badawczym, dodatkowo potęgowanym ewolucją funkcji wsi, jaka dokonuje się w ostatnich dekadach. Ponadto o rozwoju gmin wiejskich decydują nie tylko ich zmieniające się funkcje, ale również czynniki niezależne od funkcji wsi (Wójcik, 2019).

Od kilkunastu lat coraz bardziej pogłębiają się różnice w sferze społecznej, demograficznej i ekonomicznej między gminami wiejskimi. Gminy wiejskie coraz częściej starają się upodobnić do miast w jak największym stopniu, co prowadzi do tego, że między miastami a niektórymi wsiami zacierają się różnice. Zanikające różnice wpływają również na coraz mniejsze znaczenie podziału osadniczego na gminę wiejską i miasto. W wyniku wielu zmian zachodzących na obszarach wiejskich powstają wysoce rozwinięte miejscowości wiejskie leżące w pobliżu miast, stanowiące często centrum większych obszarów wiejskich (Zegar, 2016: 10).

Współcześnie coraz mniej wsi związanych jest z funkcją rolniczą. Ponad 60\% mieszkańców terenów wiejskich nie zajmuje się już produkcją rolniczą czy użytkowaniem ziemi rolnej. Obecnie wyłącznie z rolnictwa utrzymuje się już mniej niż jedna trzecia ludności wiejskiej i odsetek ten nadal maleje, a udział zatrudnienia w rolnictwie w Polsce wynosi już tylko 9,5\% (GUS, 2021). Obszary wiejskie coraz częściej upodabniają się do miast, szczególnie pod względem przemian demograficznych, które wynikają z wyboru wsi na miejsce zamieszkania przez coraz większą liczbę osób, również tych mieszkających dotychczas w ośrodkach miejskich. Zjawisko to prowadzi do wzrostu liczby ludności na obszarach wiejskich i przenoszenia miejskiego stylu życia nowych mieszkańców na te tereny, co z kolei skutkuje potrzebą rozbudowy infrastruktury wiejskiej, która w efekcie nabiera miejskich cech (Heffner, Gibas, 2014: 4-5).

Zmiany na obszarach wiejskich przybrały znacząco na sile po 2004 roku, kiedy Polska została członkiem Unii Europejskiej. Pomimo wielu problemów, z którymi zmagały się wówczas wsie, takich jak niski poziom produkcji, przeludnienie, zmiany w strukturze gospodarstw wiejskich oraz istnienie wielu słabo rozwiniętych obszarów z niepewną przyszłością, ośrodki wiejskie rozwijały się dość prężnie. Wśród przyczyn intensywnego rozwoju terenów wiejskich w ostatnich dwóch dekadach można wymienić (Stanny, Rosner, Kozdroń, 2016: 29-30):

- wprowadzenie polityki wolnorynkowej w rolnictwie, przemyśle spożywczym i handlu;

- otwarcie rynku unijnego na polskie produkty;

- nowe inwestycje;

- wzrost eksportu produktów rolno-spożywczych;

- pomoc finansową dla rolników indywidualnych oraz samorządów. 
Wszystkie te zmiany doprowadziły do wzrostu dochodów na obszarach wiejskich i poprawy jakości życia mieszkańców. Ponadto dzięki powyższym działaniom wzrosła liczba inwestycji, które przyniosły korzyści rolnikom i przedsiębiorstwom wspierającym rolnictwo.

Według Eugeniusza Niedzielskiego i Jana Rzeszutka (2010: 148) na tempo i kierunki rozwoju obszarów wiejskich wpływają czynniki historyczne, kulturowe, polityczne, technologiczne, produkcyjne, przyrodnicze, geograficzne, społeczne oraz demograficzne. Uwarunkowania historyczne i kulturowe odpowiadają za kształtowanie struktury gospodarstw, sieci osadniczej, architektury wiejskiej, a także stosunku do tradycji wiejskiej. Czynniki polityczne wynikają z systemu politycznego kraju i jego zmian oraz z krajowej i europejskiej polityki rolnej. Zmiany w technologii i produkcji odnoszą się do wykorzystywania środków chemicznych w rolnictwie, unowocześniania i zmian procesów produkcji oraz postępu biologicznego. Czynniki przyrodnicze dotyczą środowiska naturalnego, jego jakości i znaczenia, a geograficzne własności krajobrazu, lokalizacji oraz ukształtowania terenu. Ostatnia grupa czynników związana jest z gęstością zaludnienia, jakością życia ludności, poziomem wykształcenia i strukturą zawodową (Niedzielski, 2015: 87).

Z kolei według Pawła Churskiego i Roberta Perdała (2008: 21) na rozwój wsi mają wpływ trzy grupy czynników: kapitał ludzki, infrastruktura techniczna oraz czynniki miękkie. Kapitał ludzki obejmuje wykwalifikowaną i wykształconą siłę roboczą na danym terenie, która dzięki dostępowi do edukacji może dostosowywać swoją wiedzę i umiejętności do ulegających ciągłym zmianom potrzeb na rynku pracy. Drugą grupę czynników stanowi wyposażenie wsi w wodociągi, kanalizację, energię, sieć gazową, transport i usługi telekomunikacyjne. Czynniki miękkie natomiast odpowiadają za tworzenie warunków do budowy i rozwoju gospodarki opartej na wiedzy. Czynniki te obejmują wyposażenie wsi w instytucje, zdolność tworzenia skupisk przedsiębiorstw i nawiązywania współpracy, kulturę przedsiębiorczości oraz dostępność nowoczesnych technologii (Rodzoś, Wesołowska, 2013: 134).

Inny podział czynników rozwoju obszarów wiejskich dotyczy w szczególności gospodarki opartej na wiedzy. Do tego rodzaju czynników należą (Musiał, 2010: 151-153): zarządzanie, fundusze Unii Europejskiej, kapitał ludzki oraz turystyka. Zarządzanie powinno umożliwić wykorzystanie potencjału danego terenu oraz znalezienie zagranicznych inwestorów i pozyskanie środków finansowych na rozwój gminy. Fundusze unijne znacząco pomagają gminom wiejskim w rozwoju kapitału ludzkiego i infrastruktury społecznej. Dzięki unijnym środkom powstają nowe inwestycje, wyposażenie gospodarstw ulega poprawie, polepsza się również sytuacja materialna i poziom życia mieszkańców. Kapitał ludzki jest niezwykle ważnym czynnikiem rozwoju obszarów wiejskich, ponieważ dzięki niemu dokonuje się wzrost innowacyjności i przedsiębiorczości, co z kolei 
prowadzi do rozwoju gminy i osiągnięcia dobrobytu. Turystyka wpływa pozytywnie na obszary wiejskie, gdyż stanowi dla nich źródło dochodów i umożliwia rozwój funkcji nierolniczych.

Czynniki rozwoju obszarów wiejskich można rozpatrywać także w kontekście rozwoju zrównoważonego, dzieląc je na zewnętrzne, czyli ponadregionalne, oraz wewnętrzne. Zarówno wśród zewnętrznych, jak i wewnętrznych czynników rozwoju wsi wskazuje się trzy wymiary (Chmieliński, 2015: 20-21): społeczny, ekonomiczny i ekologiczny. W aspekcie zewnętrznym wymiar społeczny obejmuje edukację, stowarzyszenia i organizacje pozarządowe, zachowania konsumenckie, ochronę dziedzictwa kulturowego oraz relacje społeczeństwa z władzami gminy. Na wymiar ekonomiczny składają się przepisy prawne w zakresie prowadzenia działalności gospodarczej, założenia rozwoju i polityki sektorowej, polityka władz centralnych oraz dostępność pomocowych środków finansowych. Natomiast do wymiaru ekologicznego zalicza się przepisy prawne dotyczące ochrony środowiska, politykę ekologiczną oraz tworzenie terenów chronionych. Z kolei w aspekcie wewnętrznym wymiar społeczny charakteryzuje tworzenie społeczności lokalnych, działalność władz oraz popularyzowanie unikalnej kultury wiejskiej. Wymiar ekonomiczny obejmuje wielokierunkową specjalizację regionów, oszczędność surowców, badania w zakresie innowacji ekologicznych, wykorzystywanie kilku funkcji środowiska w tym samym czasie. Wymiar ekologiczny odnosi się do warunków przyrodniczych, różnorodności biologicznej, chronionych obszarów, które wpływają na rodzaje prowadzonej we wsi działalności (Chmieliński, 2015: 21).

Z czynnikami rozwoju gmin wiejskich związana jest także kategoria urbanizacji. Współcześnie, z powodu trwającej ewolucji obszarów wiejskich pod względem przestrzeni, pełnionych funkcji oraz systemów wartości i przekształcania ich w większe jednostki osadnicze, powoli zaczynają zanikać różnice pomiędzy pojęciami wieś i miasto, co ma swoje odzwierciedlenie w postępujących procesach urbanizacji na tych terenach. Na ogół z pojęcia urbanizacja korzystają nauki ekonomiczne, społeczne i przestrzenne. Jednak każda dyscyplina ujmuje to zagadnienie na swój sposób, podając różne definicje oraz wyróżniając odmienne formy i czynniki urbanizacji (Brol, 1996: 11).

W najogólniejszym rozumieniu urbanizacja jest procesem tworzenia miast. Mianem urbanizacji określa się także rozwój miast mierzony wzrostem liczby ludności, zwiększeniem powierzchni obszaru zajmowanego przez miasto oraz wzrostem udziału liczby ludności miejskiej w ogólnej liczbie mieszkańców gminy (Czornik, 2004: 102-103). Zgodnie z tą definicją na proces urbanizacji wpływ mają następujące czynniki (Czornik, 2008: 24-25):

- ekonomiczne, $\mathrm{tj}$. surowce naturalne, rynek usług, zakłady przemysłowe i warunki dla działalności handlowej;

- administracyjne, czyli decyzje polityczne określające dokładną lokalizację miasta; 
- $\quad$ komunikacyjne i transportowe, tj. położenie przy szlaku, drodze, linii kolejowej lub nad rzeką;

- przyrodnicze, czyli klimat, woda, nasłonecznienie oraz wiatry;

- militarne, tj. dobre warunki obronne i możliwość kontrolowania bezpieczeństwa sąsiednich wsi.

Dwie klasyczne definicje urbanizacji określają proces urbanizacji jako prosty i przebiegający jednopłaszczyznowo. Demograficzna kategoria urbanizacji Hope’a Tisdale’a wskazuje na wzrost liczby ludności zamieszkującej miasta oraz określa urbanizację jako koncentrację ludności w skali całego kraju. Z kolei Louis Wirth w socjologicznej definicji urbanizacji wyjaśnia uwarunkowania społeczne tego procesu, jakie stanowi zmiana stylu życia z wiejskiego na miejski. Według tego podejścia miejski styl życia został określony mianem urbanizmu, którego podstawą są różnice kulturowe w mieście i na wsi (Brol, 1996: 11).

Na bazie klasycznych definicji urbanizacji powstało objaśnienie tego pojęcia, łączące aspekt demograficzny z socjologicznym, zgodnie z którym urbanizacja przejawia się we wzroście liczby ludności miejskiej, liczby miast oraz ich powierzchni. Ujęcie to zakłada również, że urbanizacja wpływa na zjawiska kulturowe i społeczne w otoczeniu, a na nią oddziałuje rozwój ekonomiczny, głównie industrializacja (Jałowiecki, 1978: 7).

Urbanizację można postrzegać także w aspekcie geograficznym oraz socjologicznym. Zgodnie z tą ideą wyraża się ona w koncentracji ludności w miejscach różniących się funkcjami i instytucjami od obszarów zamieszkiwanych przez ludność wiejską oraz zakłada istnienie różnic w stylu życia ludności miejskiej i wiejskiej. Definicja ta zawiera w sobie kryterium ekonomiczne, zwane też funkcjonalnym, umożliwiające odróżnienie miasta od wsi i miejskiego stylu życia od wiejskiego. Kryterium to odnosi się do przechodzenia ludności wiejskiej do zawodów nierolniczych, co z kolei wiąże się z dążeniem obszarów wiejskich do wielofunkcyjności (Brol, 1996: 12).

Tak więc pojęcie urbanizacji ewoluuje, postrzega się je przez trzy aspekty jednocześnie. Jedna z definicji urbanizacji dzieli to pojęcie na trzy koncepcje tworzące całość. Pierwsza koncepcja odpowiada aspektowi demograficznemu i dotyczy koncentracji ludności ograniczonej przez czas i przestrzeń. Druga z koncepcji - strukturalna - skupia się na zmianach dotyczących miejsca zatrudnienia, a więc na procesie migracji ludności z obszarów rolniczych na większe tereny o innych funkcjach. Podstawą trzeciej koncepcji - behawiorystycznej - jest miejski typ zachowań ludności bez względu na środowisko fizyczne czy społeczne (Brol, 1996: 12).

Współcześnie powszechny jest pogląd nazywany wzrostem społecznej skali, według którego urbanizacja nie stanowi jedynie procesu powstawania miast, ale również określa czynniki ich powstawania i rozwoju. Z kolei z punktu widzenia przestrzeni istotą urba- 
nizacji jest ewolucja społeczeństwa - od prostych społeczności lokalnych do złożonych układów, w których jednostki połączone są ze sobą w sposób funkcjonalny. 0 stopniu zurbanizowania wsi i miast świadczy więc zakres i siła tych powiązań (Brol, 1996: 13).

Ze względu na różne przekształcenia wsi i miast pojmowanie urbanizacji jedynie w kategorii koncentracji ludności stało się niewystarczające do opisywania współczesnych procesów urbanizacji. Urbanizację należy zatem rozpatrywać również w kontekście zachodzących jednocześnie procesów demograficznych, zmian struktury ekonomicznej, przekształceń przestrzennych oraz przemian społecznych (Brol, 1996: 13).

Komisja Procesów i Struktur Urbanizacji Międzynarodowej Unii Gospodarczej przedstawiła wieloaspektową definicję urbanizacji, według której jest ona społecznym procesem charakteryzującym się przekształceniem wielkich zbiorowości bądź ich części z tradycyjnych wiejskich społeczeństw w zróżnicowaną ludność miejską. Podstawę tego przekształcenia stanowi zmiana sposobu życia, czyli miejsca zamieszkania i zatrudnienia. Według tej definicji urbanizacja jest więc zjawiskiem społecznym, które przebiega nierównomiernie pod względem czasu i przestrzeni (Brol, 1996: 15).

Większość prac i pozycji literatury poświęcona jest urbanizacji tylko w aspekcie miasta, natomiast o wiele rzadziej przedmiotem badań jest wieś, która jest równie ważnym elementem tego procesu. Urbanizacją wsi w głównej mierze zajmuje się socjologia, gdzie proces ten jest ujmowany jako przenikanie miejskich idei i wzorców do otaczających miasta obszarów wiejskich. W procesie urbanizacji wsi miasto jest źródłem idei i wzorców modernizujących społeczeństwo wiejskie, których przenikanie jest oznaką urbanizowania się obszaru wiejskiego (Brol, 1996: 18).

Bardzo szczegółową definicję urbanizacji wsi już w połowie lat siedemdziesiątych XX wieku wprowadził Witold Rakowski, który za główny element tego procesu uznał organiczną urbanizację wsi, polegającą na dążeniu ludności wiejskiej do zlikwidowania zacofania cywilizacyjnego i kulturowego. Autor wskazywał również na zjawisko tzw. profesjonalizacji zawodu rolnika. Istotą tego zjawiska jest specjalizacja gospodarstwa rolnego lub jego poszczególnych członków w konkretnej dziedzinie produkcji rolniczej, na przykład sadownictwie, warzywnictwie, hodowli drobiu (Rakowski, 1975: 25).

Równolegle z organiczną urbanizacją wsi postępuje urbanizacja zawodowa wsi, która polega na powstawaniu na obszarach wiejskich zawodów nie tylko typowo wiejskich, ale także niepowiązanych z rolnictwem. Takie zawody nie wykluczają jednak ani wsi, ani miasta jako miejsca pracy. Urbanizacja zawodowa wsi jest więc procesem podejmowania pracy w zawodach nierolniczych, prowadzącym do zróżnicowania wsi pod względem zawodowym i społecznym, a tym samym stanowi pozarolnicze źródło utrzymania ludności wiejskiej (Rakowski, 1975: 25). 
Organiczna i zawodowa urbanizacja wsi składają się na ekonomiczną urbanizację wsi, która polega na dążeniu do racjonalnego wykorzystania siły roboczej na obszarach wiejskich. Proces ten powoduje wzrost produkcji, rozwój usług, poprawę jakości życia mieszkańców oraz zanik różnic między miastem i wsią (Rakowski, 1975: 25-26).

Według W. Rakowskiego urbanizacja wsi przejawia się także w urbanizacji krajobrazowej, która obejmuje przekształcenia w krajobrazie wiejskim, wynikające ze zmian zachodzących w budownictwie oraz infrastrukturze technicznej i społecznej (Rakowski, 1975: 26).

Nakładanie się na siebie różnych efektów urbanizacji wsi prowadzi do pełnej urbanizacji wsi, która polega na osiągnięciu poziomu cywilizacyjnego i kulturowego zbliżonego do tego w miastach i regionach rozwiniętych. Wysoki poziom cywilizacyjny i kulturowy wsi prowadzi do jej ciągłego rozwoju, który nie zostaje w tyle za miastami, a dorównuje im swoją dynamiką (Rakowski, 1975: 26).

Współcześnie urbanizacja stanowi złożony i nieodwracalny proces społeczno-ekonomiczny dokonujący się na całym świecie - zarówno w miastach, jak i na wsiach. Proces ten jest związany z koncentracją ludności, postępem naukowo-technicznym, oddziaływaniem miejskiego stylu życia, przekształcaniem się wiejskich społeczności w zróżnicowane społeczeństwa o miejskim charakterze oraz z modernizacją sieci osadniczej (Szymańska, Biegańska, 2011: 15).

Miasta i wsie na całym świecie nieustannie ewoluują, zmieniają się pod względem przestrzeni, demografii czy infrastruktury. Jednak wśród wszystkich zachodzących w nich procesów można odnaleźć wspólne cechy, jakimi są tendencje rozwojowe oraz kierunki, w jakich zmierzają. Urbanizacja jest niekończącym się procesem, więc i ona odznacza się pewnymi charakterystycznymi koncepcjami czy ideami rozwoju.

Jedną ze współczesnych tendencji rozwoju urbanizacji, która występuje także na obszarach wiejskich, jest rozwój zrównoważony, który pomimo dużego zainteresowania i wielu prac na ten temat, nie ma jednej ogólnej definicji. Rozwój zrównoważony można definiować jako (Parysek, 2008: 17):

- model zagospodarowania przestrzennego;

- koncepcję dla określonych rozwiązań w zakresie rozwoju i zagospodarowania;

- proces, w którym realizowana będzie określona koncepcja rozwoju;

- paradygmat formułowania podstaw teoretycznych i metodologicznych nowego ujmowania rozwoju społeczno-gospodarczego;

- strategię przy wyznaczaniu celów oraz priorytetów rozwojowych;

- sposób określania cech przedmiotu planowania i gospodarki przestrzennej.

Bez względu na przyjętą definicję rozwój zrównoważony na pierwszym miejscu kojarzony jest ze środowiskiem przyrodniczym i społecznym. W tym aspekcie prowadzi on do harmonii w życiu człowieka, w jego środowisku (Parysek, 2008: 18). 
Reasumując, bez względu na przyjętą definicję urbanizacji o jej tempie decydują potrzeby społeczeństwa. Te specyficzne i uniwersalne potrzeby pozwalają wyjaśnić proces urbanizacji, wskazać nowe funkcje ośrodków miejskich oraz zróżnicować miasta i umieścić je w hierarchii osadniczej. Zapotrzebowanie na miasta będące wynikiem urbanizacji wsi będzie trwało tak długo, jak długo ludzie będą wykazywali potrzebę przebywania blisko siebie, by w kontaktach bezpośrednich z innymi móc przekazywać zdobytą wiedzę i umiejętności (Jewtuchowicz, Sokołowicz, Zasina, 2016: 27-28).

\section{Przekształcenia w gminach wiejskich w Polsce}

Współcześnie występuje wiele wyzwań dotyczących rozwoju obszarów wiejskich - zarówno w aspekcie społecznym, jak i gospodarczym. W gminach wiejskich dokonują się różnego typu zmiany, które nie zawsze odczy tywane są w kategoriach korzyści. W takim przypadku konieczne jest podjęcie działań minimalizujących koszty, zapobiegawczych lub też ochronnych, mających na celu przekształcenia obszarów wiejskich, prowadzone w bardziej zrównoważonym kierunku (Falkowski, 1993: 11).

Podstawową jednostką odpowiedzialną za funkcjonowanie, rozwój i przekształcenia poszczególnych obszarów wiejskich jest gmina. Władze lokalne dysponują instrumentami wywierającymi największy wpływ na mieszkańców, lokalnych inwestorów i pozostałych użytkowników gminy. W tym celu opracowywanych jest wiele planów przestrzennych i strategii rozwoju, które umożliwiają obszarom wiejskim rozwój w odpowiednim kierunku, a niekiedy również, z biegiem lat, zmianę siedziby gminy - z wiejskiej w miasto. Opracowania te zawierają uszczegółowienie możliwych przekształceń na danym terenie (Feltynowski, 2015: 208-209).

Przekształcenia jakościowe na obszarach wiejskich obejmują społeczeństwo, gospodarkę, środowisko naturalne oraz sieć osadniczą. Zależą od wielu czynników i są procesem długotrwałym. Przekształcenia funkcjonalno-strukturalne oraz przestrzenne polegają między innymi na modernizacji infrastruktury, wprowadzaniu lub adaptacji innowacji związanych z przestrzenią i jej zagospodarowaniem oraz restrukturyzacji gospodarki w gminach wiejskich.

Przemiany demograficzno-społeczne wynikają między innymi ze zjawiska stałego wyludniania się obszarów wiejskich, które powodują niekorzystne warunki przyrodnicze i niski poziom rozwoju społeczno-gospodarczego. Wyludniające się tereny z reguły znajdują się w dużej odległości od miast, centrów przemysłowo-usługowych i ważnych szlaków komunikacyjnych. Obszary te zwane są peryferyjnymi i zwykle położone są w strefach przygranicznych (Falkowski, 1993: 11). Ludność wiejska z obszarów peryferyjnych emigruje do pobliskich miast z powodu intensywnego rozwoju przemysłu 
oraz urbanizacji. Takie masowe odpływy powodują znaczne zmiany w strukturze wieku i płci na obszarach wiejskich. Również rozwój mechanizacji w rolnictwie i leśnictwie, poprawa dostępności komunikacyjnej oraz rozwój turystyki przyczyniają się do osiedlania się ludności wiejskiej w miastach, ośrodkach przemysłowych i rekreacyjnych. Na przekształcenia demograficzno-społeczne wpływa także wzrost zatrudnienia w zawodach nierolniczych, co powoduje konieczność dojazdu do pracy. Zatrudnienie w sektorach nierolniczych rozwija się głównie na obszarach podmiejskich, w bliskim sąsiedztwie ośrodków przemysłowych, turystycznych i węzłów komunikacyjnych. Tym samym na obszarach wiejskich maleje liczba osób zatrudnionych w rolnictwie i leśnictwie (Falkowski, 1993: 11-13).

Przemiany funkcjonalno-strukturalne wynikają z rozwoju na obszarach wiejskich funkcji charakterystycznych dla miast, co spowodowane jest procesami urbanizacji i uprzemysłowienia oraz rozwojem transportu. Wsie przekształciły się w obszary wielofunkcyjne, rozwijając na swoim terenie budownictwo, przemysł, transport i turystykę. Rolnictwo, leśnictwo, myślistwo i rybołówstwo, będące niegdyś podstawą funkcjonowania wsi, zostają odsunięte na dalszy plan (Falkowski, 1993: 16).

Przekształcenia przestrzenne związane są ze scalaniem gruntów oraz łączeniem gospodarstw w większe. Przemiany te pozwoliły uporządkować strukturę przestrzenną pól oraz ekonomicznie zarządzać produkcją i osiągać lepsze jej efekty. Przekształcenia przestrzenne znajdują swoje odzwierciedlenie w typach genetycznych wsi. Dzięki rozwojowi przestrzennemu obszarów wiejskich rozwijały się takie formy osadnicze jak na przykład ulicówka i wielodrożnica. Było to możliwe głównie dzięki dobrej lokalizacji i rozwojowi komunikacji. Łączenie mniejszych wsi w większe dało efekty, które można do dziś zauważyć na niektórych obszarach wiejskich (Falkowski, 1993: 22-23).

Wszystkie przekształcenia dokonujące się w gminach wiejskich są uwarunkowane określonymi czynnikami. Wśród zewnętrznych uwarunkowań przekształceń obszarów wiejskich wyróżnia się (Falkowski, 1993: 7): ustrój i politykę państwa, poziom rozwoju społeczno-gospodarczego, planowanie przestrzenne, współpracę zagraniczną oraz badania naukowe. Natomiast wewnętrznymi uwarunkowaniami przekształceń gmin wiejskich są (Falkowski, 1993: 7): warunki przyrodnicze, potencjał demograficzny i produkcyjno-usługowy, majątek trwały, ochrona środowiska, a także administracja lokalna.

Dokonujące się na obszarach wiejskich przekształcenia i zmiany mają na celu pozyskanie nowych terenów inwestycyjnych, a w późniejszym okresie również nowych inwestorów, by zlikwidować najważniejszą barierę w rozwoju przestrzennym miejscowości. Należy jednak pamiętać, że pokonywanie określonych barier rozwoju prowadzi jednocześnie do powstawania kolejnych, na przezwyciężenie których nowo powstałe miasto zwykle musi przeznaczyć nie tylko wystarczającą ilość środków finansowych, ale i czasu (Rajchel, 2018). 
Wszystkie zmiany zachodzące na obszarach wiejskich, które w efekcie prowadzą do zmiany siedziby miejscowości z wsi w miasto, związane są z kilkoma istotnymi kwestiami. Opisane przekształcenia obszarów wiejskich często prowadzą do zmian granic administracyjnych, które są szczególnie widoczne w przypadku łączenia się kilku wsi w jedno miasto. Zarówno zmiana granic, jak i zmiana siedziby miejscowości wymagają spełnienia formalnych oraz prawnych uwarunkowań przez miejscowość. Inną ważną kwestią jest też wspomniany wcześniej fakt, iż wszelkiego rodzaju zmiany i przekształcenia warunkowane są motywami władz danej miejscowości oraz sytuacją społeczno-polityczną pomiędzy władzami a mieszkańcami gminy. Dodatkowo każda najmniejsza zmiana wywołuje określone konsekwencje w przestrzeni, społeczeństwie i gospodarce (Kociuba, 2020: 100).

Na przestrzeni lat zmieniała się liczba obszarów wiejskich oraz miast, a co za tym idzie - również ich powierzchnia. Zmiany liczby gmin wiejskich oraz miast w ostatnich dziesięciu latach przedstawia Tabela 1.

Tabela 1. Liczba gmin w Polsce w latach 2010-2019

\begin{tabular}{|l|r|r|r|r|r|r|r|r|r|r|}
\cline { 2 - 11 } \multicolumn{1}{c|}{} & $\mathbf{2 0 1 0}$ & $\mathbf{2 0 1 1}$ & $\mathbf{2 0 1 2}$ & $\mathbf{2 0 1 3}$ & $\mathbf{2 0 1 4}$ & $\mathbf{2 0 1 5}$ & $\mathbf{2 0 1 6}$ & $\mathbf{2 0 1 7}$ & $\mathbf{2 0 1 8}$ & $\mathbf{2 0 1 9}$ \\
\hline Gminy ogółem & 2479 & 2479 & 2479 & 2479 & 2479 & 2478 & 2478 & 2478 & 2478 & 2477 \\
\hline Gminy miejskie & 306 & 306 & 306 & 306 & 305 & 304 & 303 & 302 & 302 & 302 \\
\hline $\begin{array}{l}\text { Gminy miejsko- } \\
\text {-wiejskie }\end{array}$ & 597 & 602 & 602 & 602 & 608 & 611 & 616 & 621 & 628 & 638 \\
\hline Gminy wiejskie & 1576 & 1571 & 1571 & 1571 & 1566 & 1563 & 1559 & 1555 & 1548 & 1537 \\
\hline Miasta ogółem & 903 & 908 & 908 & 908 & 913 & 915 & 919 & 923 & 930 & 940 \\
\hline
\end{tabular}

Źródło: opracowanie własne na podstawie danych GUS

Na podstawie powyższych danych zauważyć można wzrost liczby miast w gminach miejsko-wiejskich przy jednoczesnym spadku liczby gmin wiejskich i niezmiennej liczbie gmin miejskich. Na gminę wiejską z reguły składa się kilka mniejszych wsi, które nie zawsze przechodzą procesy urbanizacji w takim samym tempie. Oznacza to, iż - ze względu na wchodzące w skład gmin wiejskich inne wsie niezmieniające statusu osadniczego - obszary wiejskie, które przekształcają się w miasta, w efekcie zostają siedzibami gmin miejsko-wiejskich. Największy przyrost liczby miast w ostatniej dekadzie wystąpił w 2019 roku, kiedy to jedenaście gmin wiejskich zostało przekształconych w gminy miejsko-wiejskie, tym samym tworząc dziesięć nowych miast na mapie Polski. Różnica jednej gminy w tym przypadku wynika z połączenia dwóch gmin wiejskich w jedną w celu uzyskania praw miejskich. Biorąc pod uwagę dynamiczne procesy urbanizacji na terenie całego kraju, można stwierdzić, że utrzymująca się od ponad dekady tendencja wzrostowa liczby miast i spadkowa liczby wsi będzie widoczna w kolejnych latach. 


\section{Przekształcenia w wybranych gminach wiejskich}

\subsection{Metodyka badawcza}

Problemem badawczym artykułu jest odpowiedź na pytanie o to, jakie są oczekiwania lokalnych władz w kontekście przekształceń siedzib gmin wiejskich w miasta. Oczekiwania te postrzegane są w kontekście motywacji władz lokalnych do zmiany siedziby gminy, które wiążą się także z korzyściami wynikającymi z takiego procesu urbanizacji obszarów wiejskich. Rozwiązując postawiony problem, posłużono się następującymi metodami badawczymi:

- w pierwszej kolejności dokonano syntetycznej charakterystyki wybranych gmin: Urzędowa, Mielna, Wiślicy, Radoszyc, Otynia, Łagowa, Józefowa nad Wisłą, którym w latach 2016-2018 nadano status miasta; charakterystykę przygotowano w kontekście dokonujących się w badanych gminach procesów urbanizacyjnych oraz spełniania formalnych kryteriów umożliwiających przekształcenie siedziby wybranych gmin z wsi w miasto;

- następnie dokonano identyfikacji oczekiwań władz lokalnych badanych gmin odnośnie do motywacji i korzyści przekształcenia siedzib ośrodków wiejskich w miasta; informacje na temat motywacji i korzyści z przekształcenia siedzib gmin zebrano, wykorzystując technikę wywiadu ustrukturyzowanego; wywiad, ze względu na cele badania odnoszące się do oczekiwań władz lokalnych, został skierowany do osób zarządzających gminami, tj. burmistrzów, wiceburmistrzów.

W badaniach empirycznych poza wywiadem ustrukturyzowanym bazowano także na przeglądzie źródeł wtórnych (desk research), który obejmował przegląd dokumentów strategicznych, studiów uwarunkowań i kierunków zagospodarowania przestrzennego, stron internetowych oraz literatury naukowej. Wywiad ustrukturyzowany został przeprowadzony w maju 2019 roku w formie elektronicznej i telefonicznej. Kwestionariusz składał się z ośmiu pytań dotyczących wpływu różnych czynników na rozwój miejscowości, zmianę jej siedziby oraz jej przyszły pożądany stan rozwoju. Pierwsze pytanie dotyczyło przyczyny przekształcenia siedziby gminy z wsi w miasto. Kolejne cztery pytania związane były z oceną wpływu na tę zmianę czterech czynników: wzrostu liczby ludności, zmian w sferze zatrudnienia, zmiany stylu życia mieszkańców na bardziej miejski oraz przemian przestrzennych i infrastruktury. Następne pytanie odnosiło się do uwzględnienia ochrony środowiska w procesie urbanizacji zachodzącym w gminie. Ostatnie dwa pytania nawiązywały do dalszych kierunków rozwoju miasta oraz oczekiwanych konsekwencji dla miejscowości, wynikających ze zmiany siedziby w ośrodek miejski. Badaniu poddane zostały wszystkie gminy wiejskie, których siedziby przekształcono w miasta w latach 2009-2019. Stąd też pierwotnie kwestionariusz wywia- 
du został skierowany do sześćdziesięciu gmin. Ostatecznie w artykule uwzględniono wnioski wynikające z siedmiu skutecznie przeprowadzonych wywiadów z burmistrzami i prezydentami gmin.

\subsection{Przekształcenia siedzib wybranych gmin wiejskich w miasta - perspektywa procesów urbanizacyjnych}

Przedmiotem badań przedstawionych $\mathrm{w}$ artykule jest następujące siedem polskich miast: Urzędów, Mielno, Wiślica, Radoszyce, Otyń, Łagów i Józefów nad Wisłą. Wybrane gminy znajdują się w czterech województwach: lubuskim, zachodniopomorskim, świętokrzyskim oraz lubelskim, co zostało ukazane na Mapie 1.

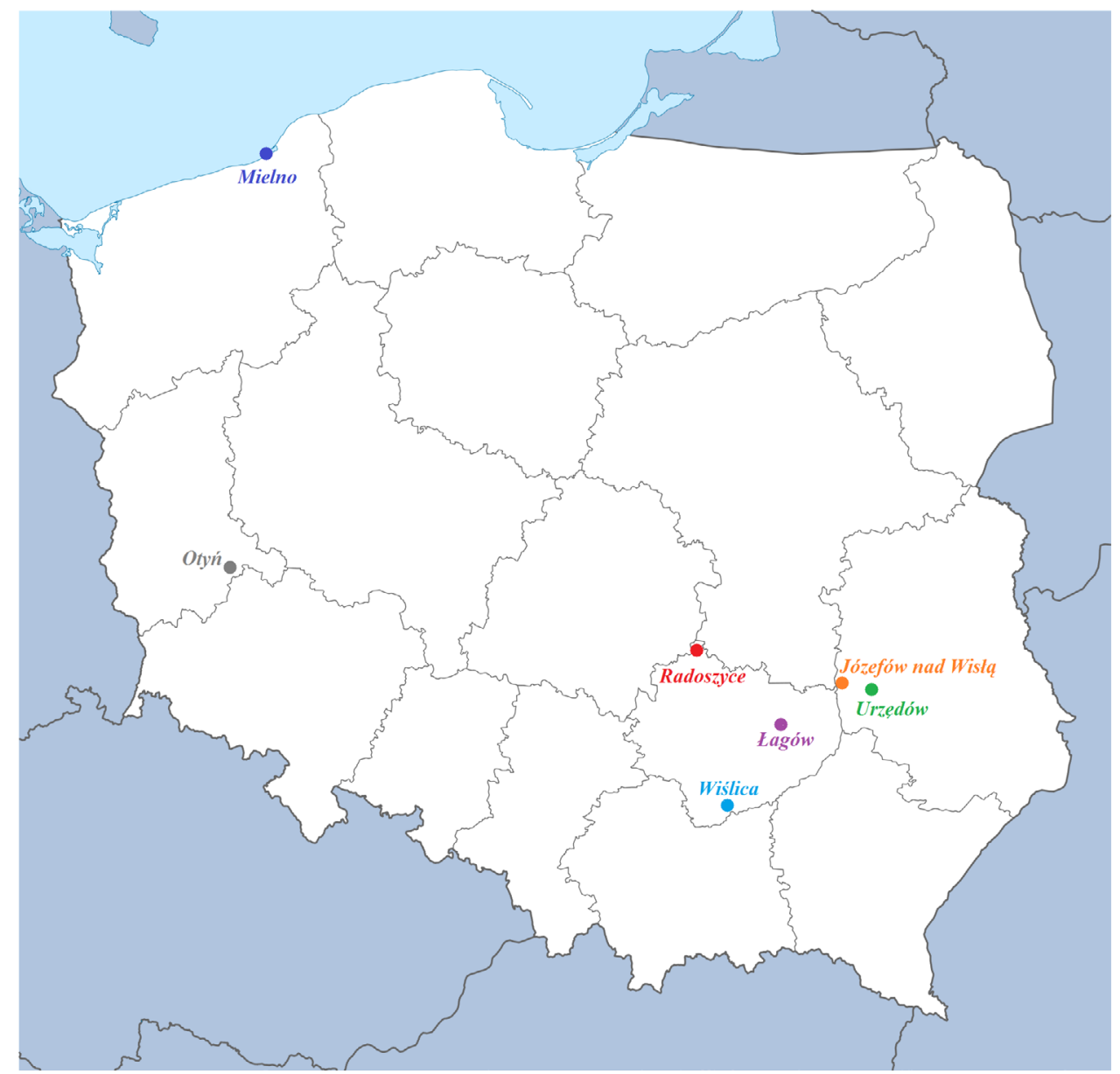

Mapa 1. Wybrane gminy na mapie Polski

Źródło: opracowanie własne

Siedziby wszystkich gmin zostały przekształcone z ośrodka wiejskiego w miasto, tym samym tworząc gminy miejsko-wiejskie. Wybrane miasta uzyskały prawa miejskie w latach 2016-2018. W Tabeli 2 zaprezentowane zostały również najważniejsze dane statystyczne dotyczące wszystkich siedmiu miast. 
Tabela 2. Dane statystyczne dotyczące wybranych siedzib gmin na 2019 rok

\begin{tabular}{|l|c|c|c|}
\cline { 2 - 4 } \multicolumn{1}{c|}{} & Liczba ludności & $\begin{array}{c}\text { Gęstość zaludnienia } \\
\text { (osób/. } \mathbf{k m}^{\mathbf{2}} \text { ) }\end{array}$ & Powierzchnia $\mathbf{( k m}^{\mathbf{2} \text { ) }}$ \\
\hline Urzędów & 1694 & 131 & 12,91 \\
\hline Mielno & 2914 & 87 & 33,45 \\
\hline Wiślica & 504 & 107 & 4,71 \\
\hline Radoszyce & 3140 & 183 & 17,17 \\
\hline Otyń & 1637 & 208 & 7,86 \\
\hline Łagów & 1562 & 190 & 8,22 \\
\hline Józefów nad Wisłą & 920 & 252 & 3,65 \\
\hline
\end{tabular}

Źródło: opracowanie własne na podstawie danych GUS

Urzędów leży w województwie lubelskim, w powiecie kraśnickim i jest siedzibą gminy miejsko-wiejskiej (Rozporządzenie Rady Ministrów z dnia 28 lipca 2015 r. w sprawie ustalenia granic...). W 2019 roku liczba ludności Urzędowa wynosiła 1694 mieszkańców, a gęstość zaludnienia 131 osób/ $\mathrm{km}^{2}$. Natomiast powierzchnia miasta wynosi 12,91 km² (GUS, 2021). W latach 1405-1870 Urzędów miał status miasta, ale utracił go wraz z upadkiem Rzeczpospolitej (Postanowienie 19 (31) grudnia 1869...). Z dniem 1 stycznia 2016 roku (Rozporządzenie Rady Ministrów z dnia 28 lipca 2015 r. w sprawie ustalenia granic...) Urzędów odzyskał prawa miejskie dzięki wnioskowi złożonemu przez Towarzystwo Ziemi Urzędowskiej i pozytywnemu wynikowi przeprowadzonego w 2014 roku głosowania wśród ludności. Z głosowania wynikało, że zmiany siedziby na miasto chcą nie tylko mieszkańcy samego Urzędowa i wsi Zakościelne, która miała zostać częścią nowego miasta, ale i okoliczne wioski oraz sołectwa, nigdy nienależące do Urzędowa i nieuwzględnione w tej koncepcji. Jak wynika z wywiadu przeprowadzonego z władzami gminy Urzędów, zabieganie o przekształcenie siedziby gminy nie było w głównej mierze wynikiem procesów intensywnej urbanizacji, a raczej wolą mieszkańców, którzy uważali, że siedziba gminy Urzędów zasługuje na miano miasta. Rozpoczęło to przygotowania do nadania statusu miasta i tym samym przekształcenia siedziby gminy wiejskiej w miasto, a pierwszy krok do tego stanowił wybór koncepcji nowego miasta. Wybrany został wariant, który nie wymuszał ponoszenia dodatkowych kosztów związanych z wytyczaniem granic. Koncepcja ta połączyła wsie Urzędów i Zakościelne w miasto o powierzchni 1290 ha i liczbie mieszkańców równej 1690 osób.

Mielno znajduje się w województwie zachodniopomorskim, w powiecie koszalińskim, nad Morzem Bałtyckim i stanowi siedzibę gminy miejsko-wiejskiej (Rozporządzenie Rady Ministrów z dnia 19 lipca 2016 r. w sprawie ustalenia granic...). Miasto zajmuje powierzchnię równą 33,45 km², z czego 22,4 km² stanowi jezioro Jamno włączone do obszaru miasta. Liczba ludności w 2019 roku wynosiła 2914 mieszkańców, a gęstość zaludnienia 87 osób/km² (GUS, 2021). Zrośnięcie się dwóch miejscowości - Mielna i Unieścia - doprowadziło do na- 
dania 1 stycznia 2017 roku (Rozporządzenie Rady Ministrów z dnia 19 lipca 2016 r. w sprawie ustalenia granic...) statusu miasta nowemu organowi miejskiemu. Z przeprowadzonego w Mielnie wywiadu wynika, że do zmiany siedziby gminy z wiejskiej w miasto w dużej mierze przyczyniła się również marka, jaką jest Mielno, a na której miało skorzystać też Unieście, będące obecnie osiedlem Mielna. Miejski charakter miejscowości oraz chęć podniesienia jej rangi w systemie osadniczym także wpłynęły korzystnie na decyzję o przekształceniu jej siedziby. Dodatkowym walorem tej decyzji była późniejsza możliwość ubiegania się o środki finansowe Unii Europejskiej dla miast. Procesy urbanizacyjne Mielna oraz Unieścia w sferze funkcjonalno-przestrzennej, które dokonywały się przez ostatnie lata, zaowocowały powstaniem rozwiniętej sieci wodociągowej, kanalizacyjnej, gazowej oraz utworzeniem oczyszczalni ścieków. Urbanizacja postępowała na tych obszarach bardzo szybko, na terenie miasta nie występuje żadna działalność rolnicza, co jest dużym atutem przy procesie przekształcania siedziby gminy wiejskiej w miasto.

Wiślica położona jest w województwie świętokrzyskim, w powiecie buskim i jest siedzibą gminy miejsko-wiejskiej (Rozporządzenie Rady Ministrów z dnia 24 lipca 2017 r. w sprawie ustalenia granic...). Według danych z 2019 roku miasto liczy 504 mieszkańców, a jego powierzchnia wynosi $4,71 \mathrm{~km}^{2}$. Gęstość zaludnienia miasta to 107 osób/km² (GUS, 2021). Wiślica miała prawa miejskie od 1326 roku do 1869 roku, kiedy utraciła je z powodu represji po powstaniu styczniowym. Miano miasta odzyskała dopiero 1 stycznia 2018 roku, zostając wówczas najmniejszym miastem Polski pod względem liczby ludności (503 osoby) (Rozporządzenie Rady Ministrów z dnia 24 lipca 2017 r. w sprawie ustalenia granic...). Przekształcenie siedziby Wiślicy w miasto miało charakter symboliczny, gdyż historia miejscowości jest starsza od państwa polskiego (Jasienica, 1978). Z wywiadu przeprowadzonego z władzami Wiślicy wynika, iż ówczesny wójt gminy uważał, że Wiślica zasługuje na miano miasta, a co z tym związane - na lepszą promocję wśród turystów i inwestorów. Takie samo zdanie mieli również mieszkańcy, którzy udzielili dużego poparcia dla tej idei, głosując za przekształceniem siedziby Wiślicy ze wsi w miasto oraz przywróceniem jej dawnej świetności. Złożenie wniosku o nadanie praw miejskich Wiślicy, a tym samym zmianę jej siedziby w ośrodek miejski nie wiązało się w znaczący sposób z procesami urbanizacji na tym obszarze. Pomimo niewielkiej liczby ludności miejscowość odznacza się miejskim charakterem zarówno zabudowy, jak i stylu życia mieszkańców. Wszelkie działania i zjawiska zachodzące w Wiślicy, takiej jak rozwój przestrzenny czy zmiana mentalności mieszkańców, były dodatkowym atutem.

Radoszyce znajdują się w województwie świętokrzyskim, w powiecie koneckim i stanowią siedzibę gminy miejsko-wiejskiej (Rozporządzenie Rady Ministrów z dnia 24 lipca 2017 r. w sprawie ustalenia granic...). W 2019 roku miasto o powierzchni równej 17,17 km² liczyło 3140 mieszkańców, a gęstość zaludnienia wynosiła 183 osoby/km² (GUS, 2021). Radoszyce w latach 1370-1870 miały status miasta, który odzyskały 1 stycznia 2018 roku (Rozporządzenie Rady Ministrów z dnia 24 lipca 2017 r. w sprawie ustale- 
nia granic...). Z przeprowadzonego wywiadu wynika, że miejscowość od dawna spełniała wszystkie wymagania, by zostać miastem. Przez ostatnie lata struktura przestrzenna była tak przekształcana, by nabrała wszystkich miejskich cech. Powstało wiele nowych inwestycji, w tym również instytucji publicznych niezbędnych w miastach, oraz rozpoczęto przebudowę głównych dróg. Gmina rozwijała się także społecznie, powstała między innymi Młodzieżowa Rada Gminy, realizująca różne projekty i pozyskująca na nie środki finansowe z zewnątrz, podejmowane były również działania mające na celu poprawę jakości życia i bezpieczeństwa mieszkańców. Choć gmina starała się o przekształcenie swojej siedziby w miasto, nie zaprzestała rozwijać sfery rolniczej, która dla miejscowości jest historycznie ważna.

Otyń położony jest w województwie lubuskim, w powiecie nowosolskim i jest siedzibą gminy miejsko-wiejskiej (Rozporządzenie Rady Ministrów z dnia 24 lipca 2017 r. w sprawie ustalenia granic...). W 2019 roku liczba ludności miasta wynosiła 1637 mieszkańców, a gęstość zaludnienia 208 osób/ $\mathrm{km}^{2}$. Otyń zajmuje powierzchnię 7,86 km² (GUS, 2021). Od 1329 roku Otyń miał prawa miejskie, które utracił w 1945 roku. Wiele różnych działań podjętych w Otyniu w ostatnich dwudziestu latach pozwoliło mu 1 stycznia 2018 roku (Rozporządzenie Rady Ministrów z dnia 24 lipca 2017 r. w sprawie ustalenia granic...) odzyskać miano miasta. Na podstawie przeprowadzonego w Otyniu wywiadu można stwierdzić, iż reformy samorządowe i administracyjne z ostatniego dziesięciolecia ubiegłego wieku zapoczątkowały nie tylko długą drogę do przekształcenia siedziby gminy Otyń, ale również procesy urbanizacji i intensywnego rozwoju miejscowości. Także społeczeństwo zaczęło się jednoczyć we wspólnej idei. Dzięki usprawnieniu organu władz i wykorzystywaniu posiadanego potencjału w ciągu kilku lat Otyń stał się administracyjnym sercem gminy. Jednocześnie intensywnie rozwijała się infrastruktura i zagospodarowanie przestrzenne całej gminy, które nabrały miejskiego charakteru i znaczenia. W efekcie ścisłej współpracy władz i mieszkańców Otyń na powrót został miastem.

Łagów leży w województwie świętokrzyskim, w powiecie kieleckim i jest siedzibą gminy miejsko-wiejskiej (Rozporządzenie Rady Ministrów z dnia 24 lipca 2017 r. w sprawie ustalenia granic...). W 2019 roku miasto liczące 1562 mieszkańców zajmowało powierzchnię 8,22 km², a gęstość zaludnienia wynosiła 190 osób/ $\mathrm{km}^{2}$ (GUS, 2021). Łagów był miastem w latach 1375-1870. W dniu 1 stycznia 2018 roku (Rozporządzenie Rady Ministrów z dnia 24 lipca 2017 r. w sprawie ustalenia granic...) prężnie rozwijający się gospodarczo i społecznie Łagów odzyskał prawa miejskie i stał się trzecim nowym miastem w województwie świętokrzyskim. Również w tym przypadku z wywiadu przeprowadzonego z władzami gminy wynika, iż o przekształceniu siedziby gminy w miasto zadecydowała historia i chęć odzyskania tego, co zostało niegdyś miastu odebrane. W związku z tym Łagów nie przechodził procesów urbanizacji tak intensywnie jak miejscowości, które o miano miasta walczyły po raz pierwszy. Łagów od czasu odebrania mu praw miejskich po powstaniu styczniowym do momentu ich odzyskania nie zmienił 
swojego miejskiego charakteru. W momencie złożenia wniosku o nadanie statusu miasta i zmiany siedziby gminy z ośrodka wiejskiego w miasto Łagów spełniał wszystkie warunki z wyjątkiem ludnościowego: pełnił funkcje nie tylko rolnicze, ale i usługowe, większość mieszkańców była zatrudniona w zawodach nierolniczych, a także charakteryzował się miejskim układem przestrzennym. Dzięki trwałemu rozwojowi całej gminy żaden czynnik nie stanowił przeszkody w odzyskaniu przez Łagów miana miasta.

Józefów nad Wisłą położony jest w województwie lubelskim, w powiecie opolskim i stanowi siedzibę gminy miejsko-wiejskiej (Rozporządzenie Rady Ministrów z dnia 24 lipca 2017 r. w sprawie ustalenia granic...). Miasto o powierzchni 3,65 km² według danych z 2019 roku liczy 920 mieszkańców, a gęstość zaludnienia wynosi 252 osoby/km² (GUS, 2021). Józefów nad Wisłą miał prawa miejskie od 1687 roku do roku 1870, kiedy utracił je w wyniku carskich represji po powstaniu styczniowym. Miano miasta odzyskał 1 stycznia 2018 roku (Rozporządzenie Rady Ministrów z dnia 24 lipca 2017 r. w sprawie ustalenia granic...) za sprawą inicjatywy Młodzieżowej Rady Gminy i poparcia jej przez resztę lokalnego społeczeństwa. Z przeprowadzonego w gminie wywiadu wynika, że mieszkańcy Józefowa nad Wisłą od zawsze zajmowali się handlem i rzemiosłem, które stanowiły źródło ich dochodów. W ciągu ostatnich dziesięcioleci miejscowość bardzo się rozwinęła, dzięki czemu nabrała miejskiego charakteru. Przede wszystkim rozwijało się tu sadownictwo i turystyka, powstały niezbędne urzędy i instytucje, a także sklepy, hotele oraz stadion piłkarski. Józefów nad Wisłą przeszedł równocześnie różne procesy urbanizacji, rozwijał się we wszystkich sektorach gospodarki i ostatecznie, z woli mieszkańców, którzy uznali, że chcieliby mieszkać w mieście zamiast na wsi, przekształcono jego siedzibę z ośrodka wiejskiego w miasto.

\subsection{Oczekiwania władz lokalnych wybranych gmin wiejskich w wyniku przekształceń siedzib gmin w miasta}

Przekształcenie siedziby obszaru wiejskiego w miasto przeważnie ma charakter czysto prestiżowy, który z zamierzenia ma być najlepszym możliwym sposobem promocji. Jednak by móc promować miasto, musi się ono rozwijać oraz odpowiadać potrzebom i oczekiwaniom zarówno mieszkańców, jak i osób przyjezdnych. Czynnikiem motywującym starania o przekształcenie siedziby gminy jest także możliwość pozyskiwania funduszy zarówno dla miasta, jak i dla obszaru wiejskiego. W tym celu gminy wiejskie przekształcają się w gminy miejsko-wiejskie, zmieniając swoją siedzibę z ośrodka wiejskiego w miasto.

Według wniosków wynikających z wywiadu przeprowadzonego w Urzędowie, którego wyniki są dość niejednoznaczne, władze miasta nie przewidują dalszego procesu urbanizacji, choć ich zdaniem miasto nadal będzie się rozwijać oraz wzmacniać swoją 
pozycję i znaczenie. W Urzędowie pożądane kierunki rozwoju, ilustrujące motywy i korzyści, jakie władze lokalne wiążą z transformacją siedziby ich gminy wiejskiej w miasto, obejmują:

- dostosowanie gminnego systemu realizacji zadań oświatowych do niekorzystnych zmian demograficznych;

- zwiększenie konkurencyjności w sektorze usług medycznych w strukturze SP ZOZ;

- maksymalne wykorzystanie funduszy unijnych na budowę ujęcia wodnego i rozbudowę sieci wodociągowej w wyznaczonym obszarze oraz remont dróg;

- inwestowanie w OZE;

- wzrost wykorzystywania odnawialnych źródeł energii;

- porządkowanie miejsc atrakcyjnych turystycznie;

- programy wsparcia skierowane do osób starszych lub niepełnosprawnych;

- rewitalizację określonego terenu miasta.

Z badania przeprowadzonego w Mielnie wynika, iż władze lokalne oprócz dalszego rozwoju miasta biorą pod uwagę także kolejne kroki w procesie urbanizacji. Władze miasta w porozumieniu z władzami okolicznych obszarów wiejskich rozważają powiększenie miasta Mielnr Według planowanej koncepcji obecne miasto miałoby połączyć się z pobliską wsią Mielenko, tym samym rozszerzając swoje terytorium. Z kolei wśród pożądanych kierunków rozwoju, uwzględniających motywy i korzyści, jakich władze Mielna oczekują w związku z transformacją siedziby gminy wiejskiej w miasto, znajdują się:

- uzyskanie środków finansowych z Unii Europejskiej na ochronę jeziora Jamno zagrożonych dewastacją oraz terenów leśnych, które zostały włączone w granice miasta;

- wzrost inwestycji;

- stopniowe eliminowanie zabudowy tymczasowej;

- większa dbałość o estetykę;

- dalsze działania w kierunku miejskiej zabudowy.

Zgodnie z wynikami wywiadu przeprowadzonego z władzami Wiślicy przekształcenie siedziby gminy w miasto otworzyło przed nią wiele możliwości rozwoju. Władze lokalne Wiślicy, najmniejszego miasta w Polsce do końca 2018 roku, postanowiły jak najlepiej wykorzystać potencjał gminy, w związku z czym opracowane zostały pożądane kierunki rozwoju, związane z motywami i korzyściami, jakich władze miejskie spodziewają się w wyniku transformacji siedziby ich gminy wiejskiej w miasto, a mianowicie:

- rozwój przestrzenny miasta;

- tworzenie nowych miejsc integracji społecznej;

- wzrost liczby ludności;

- rozwój turystyki i zaplecza gastronomicznego;

- tworzenie nowych miejsc pracy i wzrost przedsiębiorczości mieszkańców; 
- ochrona siedlisk przyrodniczych znajdujących się na terenie całej gminy, tj. parków krajobrazowych oraz obszarów chronionego krajobrazu.

Z badania przeprowadzonego w Radoszycach wynika, iż władze lokalne tej miejscowości stawiają nie tylko na rozwój miasta, ale i na kontynuację procesu urbanizacji. Ze względu na to, że urbanizacja nie przyniosła żadnych negatywnych konsekwencji, władze planują zarówno dalszą urbanizację, jak i rozwój miasta związany z ochroną środowiska. Pożądane kierunki rozwoju, dotyczące motywów i korzyści, jakie władze Radoszyc wiążą z transformacją siedziby gminy wiejskiej w miasto, prezentują się następująco:

- dalsza rozbudowa wszelkiego rodzaju infrastruktury;

- zmniejszenie bezrobocia poprzez rozwój turystyki i agroturystyki;

- rozwój szkolnictwa wyższego;

- rozwój kulturowy poprzez utworzenie miejskiego domu kultury i kina letniego;

- budowa paneli słonecznych i fotowoltaicznych;

- ochrona środowiska poprzez zastosowanie nowoczesnych rozwiązań ograniczających emisję gazów cieplarnianych, termomodernizację budynków oraz zastosowanie energooszczędnych źródeł światła;

- wzrost płac, poprawa jakości życia mieszkańców, łatwiejszy dostęp do pomocy społecznej, poprawa jakości usług medycznych i dostęp do nowych świadczeń zdrowotnych.

Zgodnie z wnioskami wynikającymi z wywiadu przeprowadzonego z władzami Otynia na przekształceniu jego siedziby w miasto skorzystała cała gmina, która stała się bardziej zauważalna przez ludzi z zewnątrz. Przedstawiciele miasta nie przewidują dalszego procesu urbanizacji, jednak postanowili wykorzystać możliwość pozyskiwania nowych środków finansowych na wspomaganie rozwoju miasta i gminy. Wśród pożądanych kierunków rozwoju, ilustrujących motywy i korzyści, jakich władze lokalne oczekują z transformacji siedziby ich gminy wiejskiej w miasto, są:

- umocnienie znaczenia organizacji pozarządowych w życiu mieszkańców;

- poprawa komunikacji między mieszkańcami a władzami;

- aktywizacja i integracja mieszkańców;

- poprawa funkcjonowania systemu opieki społecznej;

- modernizacja wszelkiej infrastruktury na terenie gminy i rozwój komunikacji miejskiej;

- wspieranie inwestorów i rozwój przedsiębiorczości;

- rozwój turystyki oraz stworzenie miejsc rozrywki i rekreacji dla mieszkańców;

- współpraca z innymi gminami;

- poprawa stanu ochrony środowiska;

- rozwój działalności kulturalnej. 
Według wyników badania przeprowadzonego w Łagowie władze lokalne planują dalszą urbanizację poprzez rozwój miasta w kierunku sektora handlowo-usługowego. Oprócz tego zamierzają powiększyć obszary terenów zielonych. Wśród pożądanych kierunków rozwoju, uwzględniających motywy i korzyści, jakie władze Łagowa wiążą z transformacją siedziby gminy wiejskiej w miasto, są:

- modernizacja infrastruktury technicznej i komunalnej;

- rozwój gospodarczy poprzez rozwój atrakcyjności regionu, konkurencyjności i przedsiębiorczości;

- ochrona i rozwój kultury, rekreacji i turystyki;

- ochrona środowiska naturalnego;

- poprawa jakości usług medycznych, publicznych i edukacyjnych;

- aktywizacja i integracja ludności wykluczonej społecznie.

Zgodnie z wnioskami wynikającymi z wywiadu przeprowadzonego z władzami Józefowa nad Wisłą planowana jest dalsza urbanizacja, głównie przez rozwój budownictwa mieszkaniowego i turystyki w regionie. Władze miejskie przewidują również dalszy rozwój miasta oraz reszty gminy. Do pożądanych kierunków rozwoju, związanych z motywami i korzyściami, jakich władze lokalne spodziewają się w efekcie transformacji siedziby ich gminy wiejskiej w miasto, należą:

- poprawa jakości życia mieszkańców;

- poprawa jakości usług medycznych, pomocy społecznej i usług edukacyjnych, w tym na poziomie przedszkolnym;

- rozwój kulturalny, a także sektora rekreacji i rozrywki;

- rozwój wszystkich rodzajów infrastruktury;

- ochrona dziedzictwa kulturowego i środowiska naturalnego;

- rozwój gospodarczy poprzez rozwój przedsiębiorczości, tworzenie nowych miejsc pracy oraz kształcenie zawodowe;

- rozwój turystyki.

W celu podsumowania wszystkich siedmiu wywiadów w Tabeli 3 zestawione zostały korzyści, jakich spodziewają się władze miejskie badanych gmin.

Tabela 3. Oczekiwania władz lokalnych w kontekście planowanego rozwoju wybranych gmin

\begin{tabular}{|l|l|}
\cline { 2 - 2 } \multicolumn{1}{c|}{} & \multicolumn{1}{c|}{ Oczekiwane korzyści } \\
\hline Urzędów & - Wzrost prestiżu \\
\hline Mielno & - Włączenie Mielenka w granice miasta \\
& - Wzrost prestiżu \\
& - Rozwój inwestycji \\
& - Pozyskiwanie funduszy z Unii Europejskiej \\
\hline
\end{tabular}




\begin{tabular}{|c|c|}
\hline & Oczekiwane korzyści \\
\hline Wiślica & $\begin{array}{l}\text { - Rozwój turystyki } \\
\text { - Rozwój inwestycji } \\
\text { - Wzrost prestiżu } \\
\text { - Pozyskiwanie funduszy z Unii Europejskiej } \\
\text { - Wzrost liczby ludności }\end{array}$ \\
\hline Radoszyce & $\begin{array}{l}\text { - Rozwój infrastruktury } \\
\text { - Rozwój turystyki i agroturystyki } \\
\text { - Rozwój szkolnictwa wyższego } \\
\text { - Wzrost prestiżu } \\
\text { - Pozyskanie funduszy z Unii Europejskiej } \\
\text { - Rozwój inwestycji }\end{array}$ \\
\hline Otyń & $\begin{array}{l}\text { - Rozwój infrastruktury } \\
\text { - Wzrost prestiżu } \\
\text { - Pozyskanie funduszy z Unii Europejskiej }\end{array}$ \\
\hline Łagów & $\begin{array}{l}\text { - Rozwój handlowo-usługowy } \\
\text { - Wzrost prestiżu }\end{array}$ \\
\hline Józefów nad Wisłą & $\begin{array}{l}\text { - Rozwój turystyki } \\
\text { - Wzrost prestiżu } \\
\text { - Rozwój inwestycji }\end{array}$ \\
\hline
\end{tabular}

Źródło: opracowanie własne na podstawie wyników przeprowadzonych wywiadów ustrukturyzowanych

Reasumując, kierunki rozwoju miasta i procesu urbanizacji są tak różne jak miasta, które je zdefiniowały. Wśród wszystkich oczekiwanych i pożądanych korzyści wynikających z przekształcenia siedziby gminy wiejskiej w miasto można jednak wyróżnić kilka wspólnych dla wszystkich badanych miast. Są nimi poprawa jakości życia, ochrona środowiska czy rozwój infrastruktury. Część gmin oczekuje, iż transformacja ich siedziby związana z urbanizacją zdynamizuje rozwój turystyki, jak na przykład Józefów nad Wisłą i Wiślica, a dla niektórych bardziej pożądane są korzyści wynikające z dalszej i prawdopodobnie szybszej urbanizacji, przykładami mogą tu być Mielno - planujące poszerzyć swoje granice czy Łagów - rozwijający sektor handlowo-usługowy.

\section{Wnioski}

Analizowane miasta nie różnią się od siebie w istotny sposób. Wszystkie należą do gmin miejsko-wiejskich, mają stosunkowo niewielką powierzchnię i liczbę mieszkańców. Prawie wszystkie, z wyjątkiem Mielna, uzyskały prawa miejskie po raz drugi. Tym, co różni badane miejscowości, jest urbanizacja, która w każdym przypadku dokonywała się inaczej, oraz związane z nią oczekiwania władz lokalnych dotyczące korzyści płynących 
ze zmiany siedziby gminy w miasto. Mniej lub bardziej intensywny proces urbanizacji zależy w głównej mierze od stanu gospodarczego gminy oraz jej potrzeb i możliwości rozwoju. Właśnie te możliwości rozwoju powodują, że czasami korzyści, których władze miejskie oczekują w efekcie transformacji siedziby ich gminy, nie znajdują później pokrycia w rzeczywistości. Wiele zależy tutaj od przebiegu urbanizacji, ale również od dalszych działań władz i samorządów. Aby efekty przekształcenia siedziby gminy wiejskiej w miasto wystąpiły i były zauważalne, trzeba stworzyć ku temu dogodne warunki i kontrolować kierunek, w którym zmierzają, by w razie konieczności móc odpowiednio szybko zareagować i osiągnąć zamierzony cel. Jest to oczywiście zadaniem lokalnych władz, które mają największy wpływ na to, jak funkcjonuje gmina.

Ze względu na zróżnicowane procesy urbanizacji oczekiwane kierunki dalszego rozwoju również są różne dla każdego miasta. Jednak dostrzec można, że wszystkie gminy dążą do poprawy jakości życia mieszkańców i stanu środowiska naturalnego oraz dalszego rozwoju wszelkiej infrastruktury. Niektóre miejscowości rozwijają się turystycznie, inne z kolei kontynuują proces urbanizacji. Zaplanowany przez władze lokalne dalszy rozwój miasta zależy w głównej mierze od tego, co udało się już osiągnąć w czasie przekształceń zachodzących w gminie. Im więcej nowa jednostka może zaoferować od siebie nie tylko swoim mieszkańcom, ale również ludności spoza miasta, tym więcej korzyści jest w stanie osiągnąć w przyszłości.

Przedstawiciele analizowanych gmin przede wszystkim spodziewają się wzrostu prestiżu miasta na tle regionu i kraju, a co za tym idzie - również podniesienia rangi miejscowości w układzie osadniczym. Jest to jak najbardziej realne postrzeganie efektów przekształcenia siedziby gminy w miasto, ponieważ ośrodek wiejski, któremu nadano status miasta, zyskuje więcej możliwości - zarówno finansowych, jak i promocyjnych. Analizując aspekt finansowy, władze lokalne równie często oczekują możliwości korzystania z kilku źródeł finansowania jednocześnie. Miasta, które zostały siedzibami gmin miejsko-wiejskich, mogą nadal korzystać z funduszy Programu Rozwoju Obszarów Wiejskich, a jednocześnie zyskują możliwość ubiegania się o środki finansowe z Unii Europejskiej na rozwój miast, dzięki czemu rozwijać może się cała gmina - zarówno nowo powstałe miasto, jak i otaczające je wsie. Z kolei na oczekiwaną promocję miasta wpływa głównie rozwój turystyki i inwestycji. Jednakże w tej kwestii nie wszystkie miasta mają taką możliwość. Rozwój turystyczny oraz wzrost konkurencyjności inwestycyjnej w regionie to korzyści, które wymagają interwencji przede wszystkim władz lokalnych. Przedstawiciele gmin często oczekują wzrostu liczby turystów oraz inwestorów w efekcie samego przekształcenia siedziby gminy z ośrodka wiejskiego w miasto, jednak by tak się stało, należy podjąć odpowiednie kroki, takie jak rozbudowa infrastruktury turystycznej, wydzielenie terenów pod potencjalne inwestycje oraz zachęcenie grup docelowych do skorzystania z oferty miasta bądź gminy. 
Reasumując, oczekiwania władz lokalnych względem transformacji siedziby gminy mogą być zupełnie różne, choć często znajdują wspólny mianownik w przypadku pozyskiwania nowych źródeł finansowania i wzrostu prestiżu. Jednak czy owe spodziewane korzyści znajdą w przyszłości odzwierciedlenie w rzeczywistości, czy też nie, zależy od osób decyzyjnych w mieście, czyli przedstawicieli jego władz. Bez względu na mniej lub bardziej realne oczekiwania władz gmin, jeśli podejmą one odpowiednie kroki i podążą w dobrym kierunku, mają dużo większe szanse na sukces. Odpowiednie wykorzystanie potencjału rozwojowego gminy jest bez wątpienia jednym z najtrudniejszych zadań, jakie czekają przedstawicieli gmin w najbliższej przyszłości.

\section{Bibliografia}

Bański J. (red.) (2013) , Polska wieś w perspektywie 2050 roku, „Studia Obszarów Wiejskich”, t. 33, Polskie Towarzystwo Geograficzne, Instytut Geografii i Przestrzennego Zagospodarowania, Polska Akademia Nauk, Warszawa.

Brol R. (1996), Procesy urbanizacji wsi polskiej, Wydawnictwo Akademii Ekonomicznej, Wrocław. Chmieliński P. (2015), Czynniki rozwoju zrównoważonego obszarów wiejskich, [w:] A. Sikorska (red.), Kierunki przeobrażeń strukturalnych oraz uwarunkowania rozwoju rolnictwa i obszarów wiejskich, Instytut Ekonomiki Rolnictwa i Gospodarki Żywnościowej - Państwowy Instytut Badawczy, Warszawa, s. 17-24.

Churski P., Perdał R. (2008), Czynniki rozwoju społeczno-gospodarczego w układzie regionalnym Unii Europejskiej, [w:] S. Dołzbłasz, A. Raczyk (red.), Europa bez granic - nowa jakość przestrzeni, „Rozprawy Naukowe Instytutu Geografii i Rozwoju Regionalnego Uniwersytetu Wrocławskiego”, nr 4, s. 21-32.

Czornik M. (2004), Miasto. Ekonomiczne aspekty funkcjonowania, Wydawnictwo Akademii Ekonomicznej w Katowicach, Katowice.

Czornik M. (2008), Miasto. Ekonomiczne aspekty funkcjonowania, Wydawnictwo Akademii Ekonomicznej w Katowicach, Katowice.

Falkowski J. (1993), Przekształcenia funkcjonalno-strukturalne i przestrzenne obszarów wiejskich Polski, Uniwersytet Mikołaja Kopernika, Toruń.

Feltynowski M. (2015), Badanie zależności między planowaniem przestrzennym a typem funkcjonalnym gmin wiejskich w obszarze bipolarnym Warszawy i Łodzi, „Biuletyn KPZK”, nr 257-258, s. 207-221.

GUS - Bank Danych Lokalnych, https://bdl.stat.gov.pl/BDL/start [dostęp: 3.12.2020].

Heffner K., Gibas P. (2014), Delimitacja przestrzenna obszarów wiejskich w województwie śląskim, Europejski Fundusz Rolny na rzecz Rozwoju Obszarów Wiejskich, Katowice.

Jałowiecki B. (1978), Społeczne zasady funkcjonowania miasta, Wydawnictwo Akademii Ekonomicznej, Katowice.

Jasienica P. (1978), W Wiślicy, [w:] P. Jasienica (red.), Słowiański rodowód, Państwowy Instytut Wydawniczy, Warszawa, s. 233-254.

Jewtuchowicz A., Sokołowicz M., Zasina J. (2016), Zrozumieć fenomen miasta, [w:] A. Nowakowska (red.), Ekomiasto\#Gospodarka. Zrównoważony, inteligentny i partycypacyjny rozwój miasta, Wydawnictwo Uniwersytetu Łódzkiego, Łódź, s. 19-28.

Kociuba D. (2020), Zmiany granic administracyjnych miast $w$ Polsce - efekty przestrzenne i społeczno-ekonomiczne, „Studia Miejskie”, nr 33, s. 99-113. 
Musiał W. (2010), Czynniki rozwoju obszarów wiejskich w gospodarce opartej na wiedzy, Wydawnictwo Uniwersytetu Rolniczego, Kraków.

Niedzielski E. (2015), Funkcje obszarów wiejskich i ich rozwój, „Zagadnienia Ekonomiki Rolnej”, nr 2, s. 84-93.

Niedzielski E., Rzeszutek J. (2010), Rozwój obszarów wiejskich na terenach popegeerowskich, „Roczniki Naukowe SERiA", t. 12, nr 5, s. 146-152.

Parysek J.J. (2008), Urbanizacja i niektóre współczesne idee, koncepcje i modele planowania rozwoju miast, [w:] J. Słodczyk, M. Śmigielska (red.), Współczesne kierunki i wymiary procesów urbanizacji, Uniwersytet Opolski, Opole, s. 11-26.

Postanowienie z 19 (31) grudnia 1869, ogłoszone 1 (13 stycznia) 1870 (Dziennik Praw, rok 1869, t. 69, nr 239, s. 471).

Rajchel D. (2018), Zmiana granic administracyjnych miasta metoda pokonania bariery przestrzennej na przykładzie Opola i Rzeszowa, [w:] S. Sitek (red.), „Stare i nowe” problemy badawcze w geografii społeczno-ekonomicznej, z. 8, s. 85-102, Polskie Towarzystwo Geograficzne Oddział Katowicki, Uniwersytet Śląski, Wydział Nauk o Ziemi, Sosnowiec.

Rakowski W. (1975), Procesy urbanizacji wsi na przykładzie woj. warszawskiego, Państwowe Wydawnictwo Naukowe, Warszawa.

Rodzoś J., Wesołowska M. (2013), Wewnętrzne uwarunkowania rozwoju obszarów wiejskich w województwie lubelskim, „Acta Universitatis Lodziensis. Folia Geographica Socio-Oeconomica”, nr 13, s. 133-151.

Rozporządzenie Rady Ministrów z dnia 28 lipca 2015 r. w sprawie ustalenia granic niektórych miast, nadania niektórym miejscowościom statusu miasta, ustalenia granic oraz zmiany nazw i siedzib władz niektórych gmin (Dz.U. z 2015 r., poz. 1083).

Rozporządzenie Rady Ministrów z dnia 19 lipca 2016 r. w sprawie ustalenia granic niektórych gmin i miast, nadania niektórym miejscowościom statusu miasta oraz zmiany nazwy gminy (Dz.U. z 2016 r., poz. 1134).

Rozporządzenie Rady Ministrów z dnia 24 lipca 2017 r. w sprawie ustalenia granic niektórych gmin i miast, nadania niektórym miejscowościom statusu miasta, zmiany nazwy gminy oraz siedzib władz niektórych gmin (Dz.U. z 2017 r., poz. 1427).

Stanny M., Rosner A., Kozdroń E. (2016), Changes in the Spatial Distribution of the Level and Dynamics of Socio-Economic Development of Rural Areas in Poland, „Wieś i Rolnictwo”, nr 4(173), s. 29-47.

Szymańska D., Biegańska J. (2011), Fenomen urbanizacji i procesy z nim zwiq̨zane, „Studia Miejskie”, t. 4, s. 13-38.

The World Bank (2020), Urban Development, https://www.worldbank.org/en/topic/urbandevelop ment/overview [dostęp: 30.11.2020].

United Nations (2018), 2018 Revision of World Urbanization Prospects, https://www.un.org/deve lopment/desa/publications/2018-revision-of-world-urbanization-prospects.html [dostęp: 30.11.2020].

Wójcik M. (2019), Funkcje wsi. Ewolucja koncepcji i współczesne wyzwania badawcze, „Studia Obszarów Wiejskich", t. 53, s. 7-18, Polskie Towarzystwo Geograficzne, Instytut Geografii i Przestrzennego Zagospodarowania, Polska Akademia Nauk, Warszawa.

Zegar J. (2016), Esej o rozwoju rolnictwa i wsi we współczesnych uwarunkowaniach, „Studia Obszarów Wiejskich", t. 42, s. 9-22, Polskie Towarzystwo Geograficzne, Instytut Geografii i Przestrzennego Zagospodarowania, Polska Akademia Nauk, Warszawa. 


\section{Transformations the Seats of Rural Communes into Cities - Expectations of Local Authorities in the Context of Urbanization}

Abstract: Nowadays, urbanization is an increasingly common phenomenon. In many countries, the number of cities and urban population is steadily increasing. Therefore, the topic of attention becomes the search for the reasons for the transformation of rural communes' seats into cities. Local authorities are the main initiators of these changes, therefore the expectations of local authorities regarding them are also interesting. The main objectives of the article are to identify the expectations of local authorities related to the transformation of the seats of rural communes into cities and to determine to what extent this change affects the benefits expected by local authorities. Motivations for transformations and the expected benefits resulting from them were analyzed on the example of seven communes in Poland: Urzędów, Mielno, Wiślica, Radoszyce, Otyń, Łagów, Józefów nad Wisłą. For this purpose, the characteristics of selected communes were made, and then, using a structured interview, the reasons for the change of the seat of the commune and the expectations of the local authorities were indicated. The conducted research shows that in most cases the local authorities expect mainly the increase in the prestige of the town and the acquisition of new sources of financing.

Keywords: $\quad$ urbanization, rural communes, transformations of seats of communes, cities

JEL: $\quad$ R58, R11, R50, R10

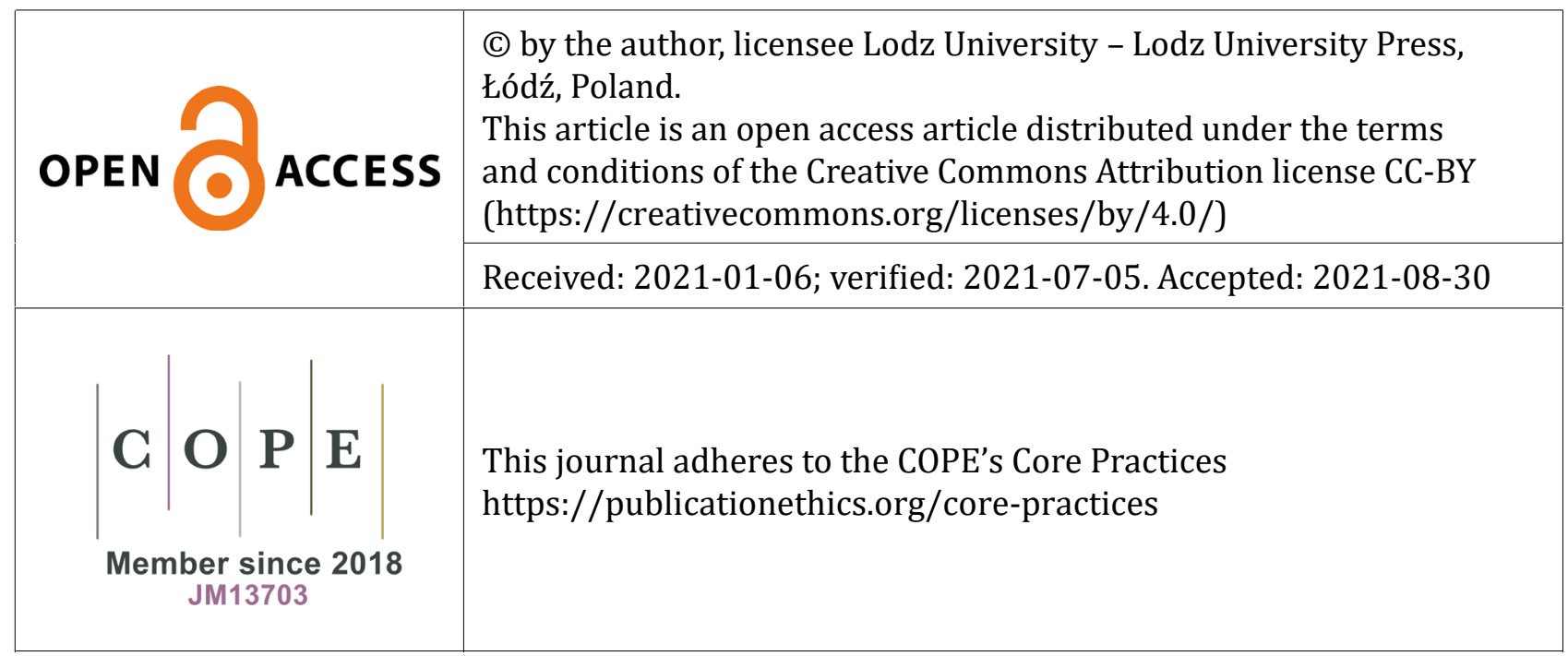

